DOI: $10.17805 / g g z .2018 .4 .8$

\title{
Виктимизация юридических лиц - жертв корпоративного мошенничества
}

\author{
А. А. Гульй
}

Московский гуманитарный университет

В статье подчеркивается, что корпоративная преступность оказывает негативное влияние на инвестиционную привлекательность России, чем обуславливает отток капитала, дестабилизирует фундаментальные факторы экономики, что опосредованно способствует спаду основных экономических показателей, в том числе росту инфлячии, снижению производства, теневизачии экономики. Основным видом экономических преступлений, с которым сталкиваются компании и в России, и в других странах мира, является незаконное присвоение активов путем моченничества. Виктимизация хозяйствующих субъектов (организаций) продолжает увеличиваться, вместе с потерями жертв корпоративного моченничества. В работе приводится характеристика жертв корпоративного моченничества.

Статья подготовлена на основе доклада на Всероссийской научной конференции «Моисеевские чтения» (Москва, 26 июня 2018 г.).

Ключевые слова: моченничество; виктимизация; жертвы; организаичи; компании; личность; преступник

\section{Victimization of Legal Entities - Victims of Corporate Fraud}

\author{
A. A. Gulyi
}

Moscow University for the Humanities

The article emphasizes that corporate crime has a negative impact on the investment attractiveness of Russia. It causes capital outflow, destabilizes the fundamental factors of economics and indirectly contributes to the decline in the main economic indicators, including inflation rate, decrease in production, shadow economy expansion. The main type of economic crime faced by companies both in Russia and in other countries of the world is the misappropriation of assets through fraud. Victimization of business entities (organizations) continues to increase, along with the losses of corporate fraud victims. The article presents the characteristics of victims of corporate fraud.

The article comprises the main points of the report presented at the all-Russian conference "Moiseev Readings" (Moscow, June 26, 2018). 
Keywords: fraud; victimization; victims; organizations; companies; personality; criminal

В Концепции долгосрочного социально-экономического развития Российской Федерации на период до 2020 года, утвержденной распоряжением Правительства РФ от 17.11.2008 № 1662-р, определены приоритеты в сфере обеспечения правопорядка и противодействия преступности. Среди них: «обеспечение равной защиты прав собственности на объекты недвижимости, предотвращение и пресечение рейдерских захватов; сокращение количества контрольных и надзорных мероприятий, проводимых в отношении малого бизнеса; противодействие легализации (отмыванию) денежных средств или иного имущества, приобретенных преступным путем; борьба с коррупцией» (цит. по: Проект Постановления ..., 2018: Электронный ресурс). Таким образом, декриминализация российской экономики (Букарев, Трунцевский, Шулепов, 2007) является приоритетным направлением деятельности государства (Трунцевский, 2011: 24).

В России значительно выросло количество сообщений о фактах мошенничества. В 2018 г. 66 \% опрошенных руководителей компаний в России заявили о том, что их компании столкнулись с экономическими преступлениями (Противодействие мошенничеству ... , 2018: 5).

Виктимизация (от лат. victima - жертва), как правило, принимает одну из двух форм: виктимизация организаций или виктимизация людей. Имеются существенные доказательства, указывающее на то, что виктимизация хозяйствующих субъектов (организаций) продолжает увеличиваться и что потери, полученные жертвами мошенничества, значительно превышают, например, уличные преступления (Truntsevsky et al., 2018). Учитывая, что многие жертвы мошенничества неохотно заявляют о своем статусе жертвы, для сотрудников системы уголовного правосудия это серьезная проблема, которая подтверждается официальной статистикой.

Корпоративным мошенничеством является использование знания для личного обогащения через преднамеренное неправильное употребление или неправильное использование ресурсов организации или активов, отмечается в докладе Ассоциации сертифицированных специалистов по расследованию хищений (Report to the nations ..., 2016: Электронный ресурс).

Это определение может быть далее разделено на три категории профессионального мошенничества: незаконное присвоение актива, коррупция и мошеннические заявления. Примерами незаконного присвоения актива является кража денежных средств или другого инвентаря. Практика показывает, что незаконное присвоение актива - самая распространенная форма корпоративного мошенничества. Примеры коррупции - это взяточничество и дру- 
гие формы неправомерного использования влияния в деловых сделках. Наконец, примерами мошеннических отчетов является фальсификация денежных документов организации или других (т. е. нематериальных) документов, таких как резюме сотрудника или доверенности.

Хотя характер этих форм мошенничества варьируется, они рассматриваются как нарушения доверия, потому что идут против доверенных обязанностей работника к организации. Профессиональное мошенничество является формой преступности белых воротничков (Benson, Simpson, 2009).

Исследование показало, что мужчины совершают чуть больше половины корпоративных мошенничеств. Большинство из них занимали должности сотрудника горизонтального уровня, в отличие от менеджеров или руководителей высшего звена, средний возраст нарушителей составил 41 год и большинство из них имели высшее образование. Женщины более рациональны в отличие от своих коллег-мужчин, они часто мотивируют мошенничество (Ищук, 2017: 104) уходом за членами семьи (например, для оплаты медицинских счетов за больным ребенком). Возможности совершить мошенничество связаны с положением преступника в пределах организационной иерархии.

Итак, типичный корпоративный мошенник, это:

- мужчина;

- около 40 лет (65 \% между 36 и 45 годами);

- женат, в среднем имеет двух детей;

- ведет активный образ жизни;

- умен и хорошо образован;

- производит впечатление уверенного в себе и честного человека;

- зачастую работает с конфиденциальной информацией;

- трудоголик (не любит пускать кого-либо в свою зону ответственности).

Доступные данные показывают, что нет никакого набора признаков «типичной» организации, преследуемой корпоративным мошенничеством: частные компании (32,1\%), открытые акционерные общества (30,8 \%), правительственные учреждения $(24,8$ \%) и некоммерческие организации $(11,2$ \%).

Организация, ставшая жертвой мошенников, - это:

- частная (42\%) или публичная (32\%) компания;

- обычно небольшая (менее 100 сотрудников), хотя размер не оказывает значительного влияния (организации менее 1000 сотрудников - 55 \% выявленных случаев, организации более 1000 сотрудников - 45 \%).

В небольших организациях мошенничество с зарплатой и подделка кассовых документов встречается вдвое чаще, чем в крупных, а коррупция наоборот. Больше всего нарушений (по количеству) происходит в банках и финансовых институтах, а самые крупные нарушения — в горнодобывающей 
промышленности. Отчетность такой организации обычно аудируется (76 \%) и в организации принят кодекс корпоративного поведения (70 \%), но формализованной программы противодействия мошенничеству обычно нет (менее $40 \%)$.

Несмотря на потери, понесенные жертвами мошенничества, многие организации отказываются к применению формальных судебных мер против преступников и вместо этого принимают решения разбираться с нарушителями внутри компании. Среди тех жертв, которые не подавали в суд, страх относительно гласности был первичной причиной, далее следовали опасения, что судебный иск был бы слишком дорогостоящим, отсутствие доказательств и страх относительно встречного иска.

Средний размер убытка в результате одного случая мошенничества 160 тыс. долларов. Примерно 25 \% случаев - более 1 млн долларов.

Присвоение активов - самый распространенный вид мошенничества (86 \% случаев), коррупция - 33 \%, искажение финансовой отчетности 5 \%. Средние потери по видам мошенничества распределены в обратной пропорции: присвоение активов - 135 тыс. долларов, коррупция - 250 тыс. долларов, искажение финансовой отчетности - 4,100 тыс. долларов.

Основной способ выявления мошенничества - «по наводке» (этот результат не изменяется с 2002 г.).

Малые организации более страдают от корпоративного мошенничества, чем большие, в силу менее развитых систем по противодействию мошенничеству. Банки и финансовые институты - самый подверженный мошенничеству сектор экономики.

Организации, внедрившие основные элементы системы противодействия мошенничеству, страдают от мошенничества реже и несут меньшие потери.

Более $80 \%$ злоупотреблений совершили сотрудники департаментов производства, продаж, финансов, закупок, обслуживания клиентов или представители высшего менеджмента. Более 85 \% злоумышленников «попались» в первый раз. В $43 \%$ выявленных случаев злоумышленники жили не по средствам, еще 36 \% испытывали значительные финансовые трудности.

Перспективным направлением исследования мошенничества (Ларичев, Трунцевский, Баграев, 2007) является экспертиза взаимоотношений жертвы и правонарушителя. Это исследование предполагает, что общая основная черта - низкий самоконтроль - частично объясняет взаимоотношения между мошенническим правонарушением и воздействием преследования. Эти данные согласуются с изучением мошеннического преследования касательно взаимосвязи между низким самоконтролем и правонарушениями, а также исследованиями, отмечающими низкий самоконтроль в качестве фактора риска 
для преследования. Это подтверждает связь между низким самоконтролем и мошенническими правонарушениями. Сотрудники с низким самоконтролем, как правило, принимают импульсивные решения, склонны к рискованному поведению и, скорее всего, действуют с целью получить быструю отдачу от небольших инвестиций.

Насильственные преступления (например, нападение) наиболее часто совершаются в отношении тех, кого правонарушитель знает лично. Проведенные исследования показывают, что характер многих форм мошенничества и преследования (например, онлайн-мошенничества) не требует личных отношения между жертвой и преступником. Тем не менее, определенные дополнительные аспекты в отношениях между исполнителем преступления и жертвой все же необходимы. Другие формы мошенничества преследования (например, кражи кредитных карт) более легко совершаются теми преступниками, которые уже имеют сложившиеся отношения с жертвой (например, члены семьи). Исследователи должны попытаться определить отношения между жертвой и правонарушителем, а также рассмотреть вопрос о других формах преследования (Трунцевский, 2010: 172), которые связаны с мошенничеством.

Итак, в результате корпоративного мошенничества организация несет значительные финансовые потери. Во многих случаях в конечном итоге ущерб несут и те, кто непосредственно не является объектом этих преступлений (например, широкая общественность). Поскольку технологии продолжают развиваться, коммерсанты-жертвы будут по-прежнему сталкиваться с мошенническими действиями, поэтому ученым и чиновникам системы уголовного правосудия необходимо искать пути решения проблемы мошенничества.

Существует два основных подхода к противодействию корпоративному мошенничеству (Кафтайлова, Ручкин, Трунцевский, 2010: 42). Первый основан на стремлении полностью искоренить это явление. Второй предполагает управление риском мошенничества аналогично тому, как ведется управление любым другим риском. Практика показывает, что бороться стоит лишь с таким мошенничеством, которое грозит бизнесу ощутимым уроном. Тратить же силы и деньги на мелкий обман далеко не всегда оправданно. Поэтому следует сначала определить, какие риски нужно взять под контроль в первую очередь.

Меры по выявлению признаков мошенничества:

- анализ существующей системы внутреннего контроля;

- проведение аналитических процедур (анализ и сравнение различных финансовых и нефинансовых показателей);

- проведение интервью с потенциальными свидетелями; 
- проведение детальных тестирований на основании выборки (нетипичные транзакции, договоры и т. п.);

- внеплановая инвентаризация.

\section{СПИСОК ЛИТЕРАТУРЫ}

Букарев, В. Б., Трунцевский, Ю. В., Шулепов, Н. А. (2007) Зарубежный опыт в сфере правового регулирования противодействия легализации (отмыванию) доходов, приобретенных преступным путем // Международное публичное и частное право. № 4. С. 53-64.

Ищук, Я. Г. (2017) Значение мотива и мотивации «криминальной личности» для оперативно-розыскной профилактики преступлений // Актуальные вопросы совершенствования деятельности служб и подразделений полиции в области охраны общественного порядка и обеспечения общественной безопасности : сб. ст. Всероссийской науч.-практич. конф. (Москва, 9 декабря 2016 г., Академия управления МВД России). М. : Академия управления МВД России. 291 с. С. 100-105.

Кафтайлова, Е. В., Ручкин, О. Ю., Трунцевский, Ю. В. (2010) Реорганизация юридических лиц (правовые основы) : науч.-практич. пособие. М. : Издат. группа «Юрист». 120 с.

Ларичев, В. Д., Трунцевский, Ю. В., Баграев, С. П. (2007) Методика криминологического исследования налоговой преступности (вопросы совершенствования) : монография. М. : Издат. дом Шумиловой И. И. 184 с.

Проект Постановления Правительства Российской Федерации «О внесении изменений в государственную программу Российской Федерации "Обеспечение общественного порядка и противодействие преступности”” (подготовлен МВД России 27.12.2017) (2018) [Электронный ресурс] // Гарант.ру. 18 января. URL: http://www.garant.ru/products/ipo/prime/doc/56640597/ (дата обращения: 29.06.2018).

Противодействие мошенничеству: какие меры принимают компании? Российский обзор экономических преступлений за 2018 год. (2018) 28 с. [Электронный ресурс] // PwC в России. URL: https://www.pwc.ru/ru/forensicservices/assets/PwC-recs-2018-rus.pdf [архивировано в WaybackMachine] (дата обращения: 29.06.2018).

Трунцевский Ю. В. (2011) О проблемах правового регулирования взаимоотношений государства и бизнеса // Юридический мир. № 4. С. 20-24.

Трунцевский, Ю. В. (2010) Российское уголовно-превентивное право: признаки отрасли // Российский криминологический взгляд. № 3. С. 165-173.

Benson, M. L., Simpson, S. S. (2009) White-collar crime: An opportunity perspective. N. Y. : Routledge. xii, $240 \mathrm{p}$.

Report to the nations on occupational fraud and abuse (2016) [Электронный pecypc] // Association of Certified Fraud Examiners. URL: http://www.acfe.com/ rttn2016.aspx [архивировано в WaybackMachine] (дата обращения: 29.06. 2018). 
Truntsevsky, Yu. V. et al. (2018) A smart city is a safe city: The current status of street crime and its victim prevention using a digital application / Yu. V. Truntsevsky, I. I. Lukiny, A. V. Sumachev, A. V. Kopytova // MATEC Web of Conferences. Vol. 170. Article No. 01067. DOI: 10.1051/matec conf/201817001067

Дата поступления: 7.07.2018 г.

Гульй Антон Андреевич — кандидат юридических наук, доцент кафедры уголовно-правовых и специальных дисциплин Московского гуманитарного университета. Тел.: +7 (499) 374-73-80. Эл. адрес: kafedraup@mosgu.ru

Gulyi Anton Andreevich, Candidate of Law, Associate Professor, Department of Criminal, Legal and Special Disciplines, Moscow University for the Humanities. Tel.: +7 (499) 374-73-80. E-mail: kafedraup@mosgu.ru

Для циитирования:

Гулый А. А. Виктимизация юридических лиц - жертв корпоративного мошенничества [Электронный ресурс] // Горизонты гуманитарного знания. 2018. № 4. C. 152-158. URL: http://journals.mosgu.ru/ggz/article/view/850 (дата обращения: дд.мм.гггг). DOI: 10.17805/ggz.2018.4.8 